\title{
Soil Detachment with Organic Mulching Using Rainfall Simulator in Comparison with a Short Duration Natural Rainfall for Effective Soil Conservation
}

\author{
Johnson Kayode Adewumi1, John Jiya Musa2², Olayemi Johnson Adeosun1, \\ Otuaro Ebierin Akpoebidimiyen' ${ }^{3}$, Adebola Adekunle ${ }^{4}$, Babafemi Sunday Adewumi1
}

${ }^{1}$ Department of Agricultural \& Bioresources Engineering, College of Engineering, Federal University of Agriculture, Abeokuta, Nigeria

${ }^{2}$ Department of Agricultural \& Bioresources Engineering, School of Infrastructure, Process Engineering and Technology, Federal University of Technology, Minna, Nigeria

${ }^{3}$ Department of Civil Engineering, Faculty of Engineering, Maritime University, Okerenkoko, Nigeria

${ }^{4}$ Department of Civil Engineering, College of Engineering, Federal University of Agriculture, Abeokuta, Nigeria

Email: *johnmusa@futminna.edu.ng

How to cite this paper: Adewumi, J.K., Musa, J.J., Adeosun, O.J., Akpoebidimiyen, O.E., Adekunle, A. and Adewumi, B.S. (2020) Soil Detachment with Organic Mulching Using Rainfall Simulator in Comparison with a Short Duration Natural Rainfall for Effective Soil Conservation. Journal of Environmental Protection, 11, 457-469. https://doi.org/10.4236/jep.2020.116027

Received: April 23, 2020

Accepted: June 19, 2020

Published: June 22, 2020

Copyright $\odot 2020$ by author(s) and Scientific Research Publishing Inc. This work is licensed under the Creative Commons Attribution International License (CC BY 4.0).

http://creativecommons.org/licenses/by/4.0/ (c) (i) Open Access

\begin{abstract}
The impact of raindrop on sandy soil was studied using rainfall simulator and natural rainfall to determine average soil detached. Erosion by rainfall is one of the major hazards threatening the productivity of farmlands. This study determined the rate of soil detachment in comparison between natural rainfall and simulated rainfall for effective soil conservation measure. The height of the simulator was varied considering the diameter of the nozzles which were considered during the design stage of the rain simulator. Two plots of dimensions $2 \mathrm{~m} \times 2 \mathrm{~m}$ each were cleared with one considered for bare and treated soils for both the natural rainfall and simulated rainfall. Splash cups were installed on each of the plots at half depth of the cup after the clearing of the area at $0.4 \mathrm{~m} \times 0.4 \mathrm{~m}$ apart. Two sets of rain gauge were placed at the experimental site to note the volume of natural rainfall on the farm. The average soil detached was analysed using statistical analysis where t-test was also carried out to know the difference in mean. There was a significant difference in the degree of soil detachment between bare and treated soil under natural rainfall experiment; $\mathrm{t}(18)=8.917, \mathrm{p}<0.01$. The mean of the natural rainfall for the bare soil was 11.6910 compared to that of the treated soil of 7.75. Size of effect (Eta-square $\left.\left(\eta^{2}\right)=0.8154\right)$ reveals that the nature of soil accounted for $81.5 \%$ variance in the average detachment rate. For simulated experiments with a mean value of 7.3360 have higher tendency of detachment than treated soil with a mean value of 4.2240 . Size of effect (Eta-square $\left.\left(\eta^{2}\right)=0.630\right)$ re-
\end{abstract}


veals that the soil types accounted for $63 \%$ variance in the average detachment. It was concluded that $40.33 \%$ soil was found to be conserved using the cow dungs mixed with bare soil to compact the soil. The nozzle size, simulator height, rainfall intensity and other rainfall parameters all contributed to the amount of average soil detached.

\section{Keywords}

Bare, Rainfall, Simulator, Soil, Treated

\section{Introduction}

The process of soil erosion by water comprises of two main agents (wind and water), which causes the detachment and transportation of soil particles. Drop impact and runoff are complementary processes that occur separately or in combination [1] [2]. Raindrop impact sets in when the first raindrop strikes the soil, and through its capacity to detach soil particles, this process represents the first stage in soil erosion by water [3] [4]. Soil detachment is defined as the dislodgment of soil particles from the soil mass at a particular location on the soil surface [2] [5]. The dislodgment is caused by the forces of impact on the soil which occurs primarily through the process of rain splash and later becomes the overland flow [6] [7] [8]. Four basic detachment and transport processes have been identified, including detachment by raindrops, detachment by flowing water, transport by raindrops, and transport by flowing water. Different types of erosion can occur within a field depending on soil detachment, transport and detachment methods [9] [10]. The most common types of water erosion observed in agricultural fields are splash, sheet, rill and inter rill erosion [11] [12].

Mulching soil is one of the best management practices (BMPs) to control erosion on sloping lands [13] [14]. The effectiveness of a wide range of mulch materials on reduced soil detachment, transport, and modifying hydraulic characteristics of runoff has been widely studied under simulated rainfall and field conditions by several researchers [15] [16] [17] [18].

Sediment flow has a relationship between the impact of rain drop and the detachment rate of soil by flow. Wang et al. [19] studied explicitly the impact of sediment load on detachment rates in rills, and showed that both bed load and suspended load significantly reduce detachment rates in rills. Turbulence is a necessary and critical component of detachment of soil by flowing water [20]. This phenomenon is commonly referred to as a sediment feedback relationship [21] [22]. The main objective of this project is to determine the rate of soil detachment in comparison with natural rainfall for effective soil conservation.

\section{Materials and Methods}

\subsection{Study Site Description}

The project was carried out on the College of Engineering Experimental Farm at 
Federal University of Agriculture, Abeokuta in Ogun state which is situated northeast of Abeokuta, the capital of Ogun State. It lies between longitudes $3^{\circ} 26^{\prime} 32^{\prime \prime} \mathrm{E}$ and latitudes $7^{\circ} 13^{\prime} 52^{\prime \prime} \mathrm{N}$ the land mass of the site is five Hectares $(5 \mathrm{Ha})$ and lies within the geographical boundary of Odeda Local Government Area Abeokuta, Ogun State, Nigeria.

Land slope of the locations varied between $2 \%$ and $3 \%$. The vegetation is mainly secondary forest. The annual rainfall is $1200 \mathrm{~mm}$. Particle size distribution investigated revealed that the soil texture at both locations was sandy loam [23]. The dominant soil in the study locations is classified as an Alfisol.

\subsection{Site Set Up}

The farm land area that was used to carry out the experiment was cleared to maintain a bare soil so as not to disturb the soil. A topographic survey was carried out to know the dimensions and the slope of the land; also the latitude and longitude of the location were determined. Two plots dimension of $(2 \times 2) \mathrm{m}$ was cleared, the first plot was bear soil and the second plot was treated soil (soil mixed with cow dungs) that serves as a control to the experiment. Experiment was conducted both for natural rainfall and rainfall simulator on the site. Splash cups were installed on the farm site at half depth of the cup after the clearing of the area at $(0.4 \times 0.4) \mathrm{m}$ apart. Two sets of rain guage were placed at the farm experimental site to note the volume of natural rainfall on the farm.

After each rainfall, the detached soil that fell into the splash cup was taken and oven dry and the soil detached measured, after which the splash cup was reinstalled before the next rainfall. To avoid sediment loss, some drainage is allowed with small holes at the edges of the cups to allow drainage. A porous membrane allows water drain out slowly but prevents sediment loss from the cup. The classical method for quantifying detached soil relies on the use of detach cups, or small traps that collect soil particles detached and transported by splash [24] [25].

The rainfall simulator was constructed at the soil and water laboratory and was taken on to the experimental farm site, which was used alongside the natural rainfall as a control. It was designed and constructed with pulverized pipes.

\subsection{Nozzle Size Diameter}

Four different nozzles size diameter were factored into the rainfall simulator of $0.5 \mathrm{~mm}, 0.59 \mathrm{~mm}, 0.67 \mathrm{~mm}, 0.78 \mathrm{~mm}$ respectively. The various sizes were factored into the design to determine the raindrop size effect on the amount of soil detachment and also used to predict the natural rainfall drop where there's no electronic device to detect the size of raindrop. Plate 1 presents the various sizes of nozzles used during the study period.

The rainfall simulator was installed on the experimental farm site with the temporary water supply tank positioned at a constant pressure head height of 3 $\mathrm{m}$. The simulated rainfall experiment was carried out at different heights to see the effects on the soil detached. Five levels of heights were varied which was at 
$1.0 \mathrm{~m}, 1.5 \mathrm{~m}, 2.0 \mathrm{~m}, 2.5 \mathrm{~m}, 3.0 \mathrm{~m}$ respectively. Figure 1 shows the rainfall simulator set up while Figure 2 shows the front elevation of the rain fall simulator and Figure 3 shows the combination of the simulated rainfall and the natural rainfall experimental sites. The experiment was run for 5 minutes each, the detached soil of both the simulated rainfall and the natural rainfall was varied to see the difference and to see the effect of the treated soil as a conservative measure to be used.
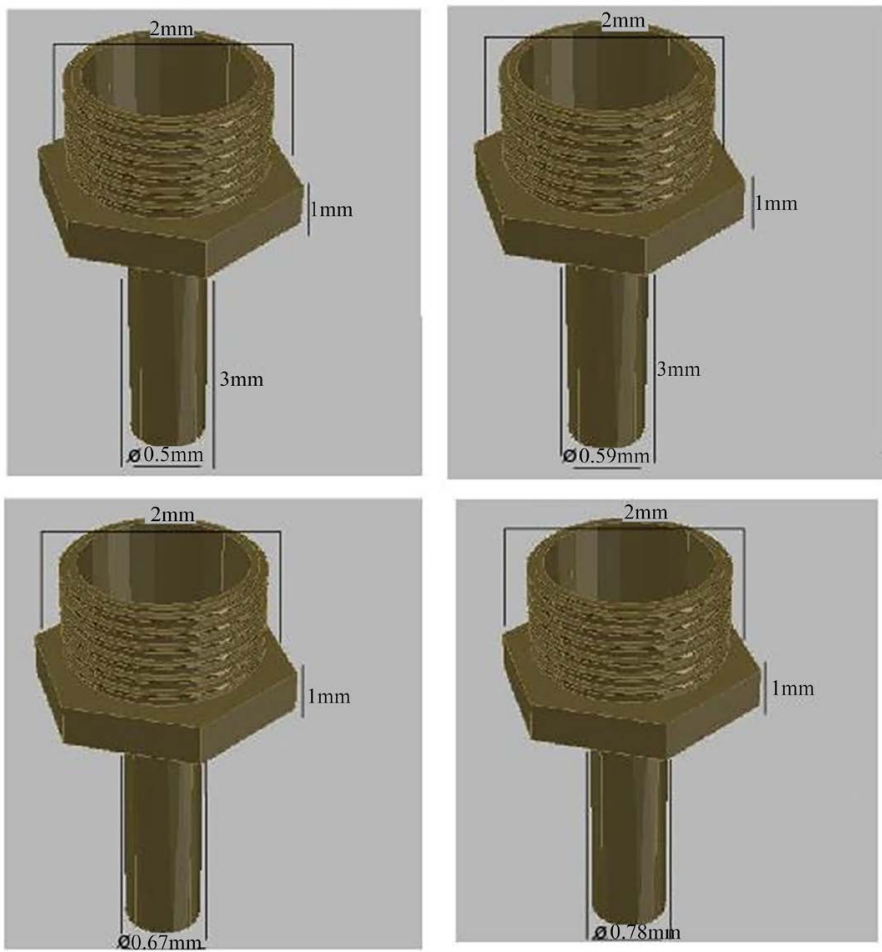

Plate 1. Different Nozzle size diameter.

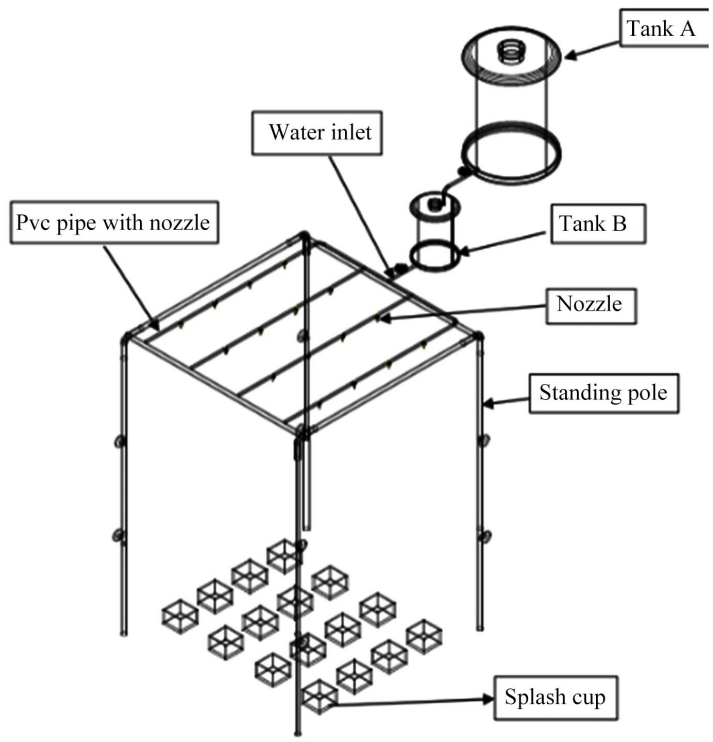

Figure 1. Rainfall simulator set up. 


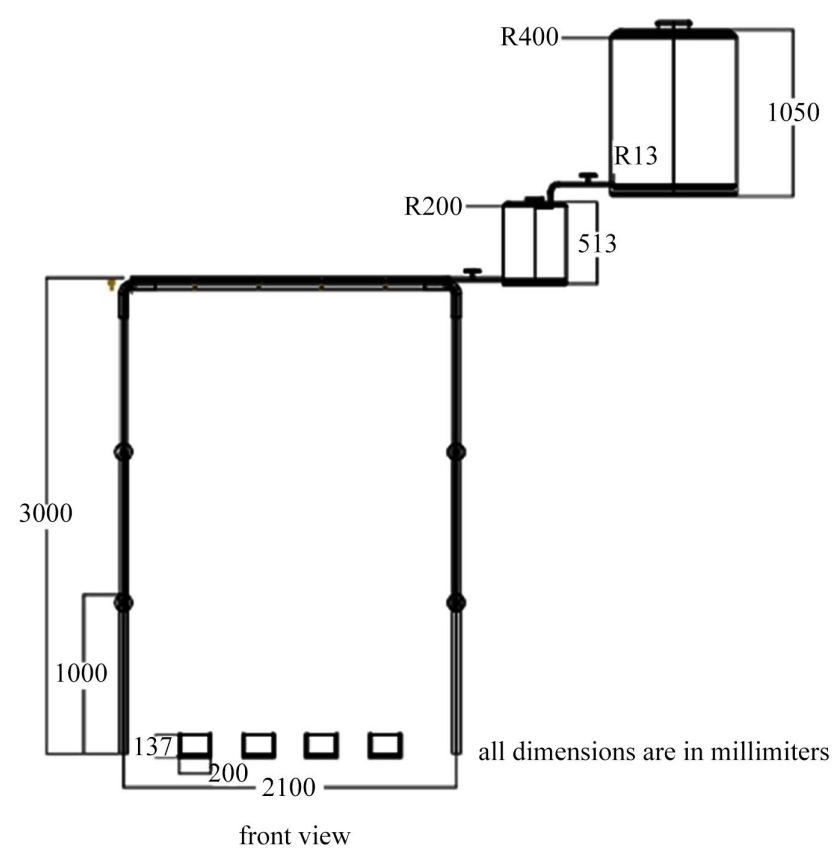

Figure 2. Front view of rainfall simulator.

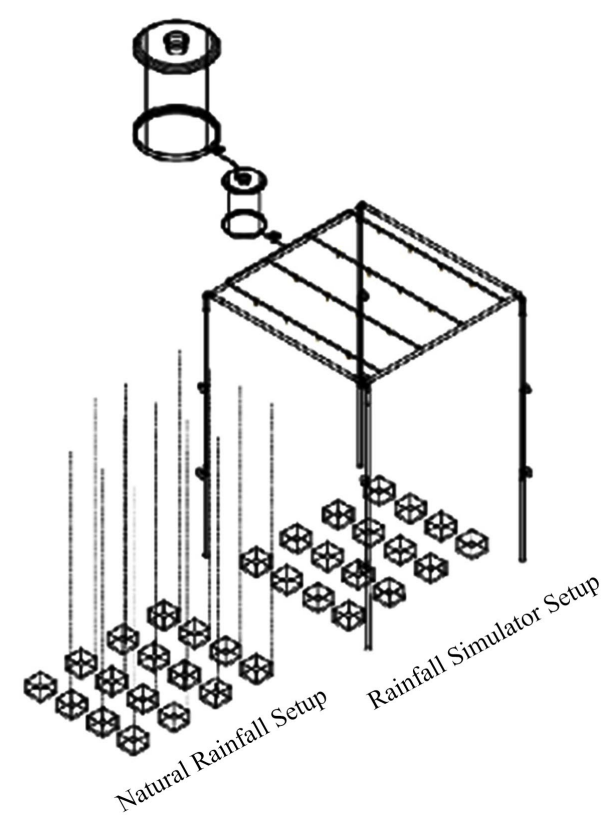

Figure 3. Natural and simulated rainfall setup.

\section{Results and Discussion}

The relationship between the rainfall event, volume, intensity and the kinetic energy under natural rainfall event as it contributes to the soil detachment process is presented in Table 1. Rainfall characteristics (e.g. rainfall intensity, raindrop kinetic energy) and soil detached were assessed and calculated from equation developed by Adewumi (1998) which is presented as in Equation (1).

$$
\text { K.E }=14.38 \mathrm{InRa}-10.43\left(\mathrm{~J} / \mathrm{m}^{2} / \mathrm{mm}\right)
$$


Table 2 presents the comparison of the degree of detachment between bare and treated average soil under natural rainfall which reveals that there is a significant difference in the degree of soil detachment $(t(18)=8.917, p<0.01)$. It was also observed from the same table that the bare soil had a mean detachment rate of 11.69 when compared to that of the treated soil of 7.74. This implies that the bare soil had a higher tendency of detachment than treated soil. This is similar to the findings of [26] and [27]. They recorded results the effectiveness of plants and vegetation in erosion control and restoration area and the effects of rock fragment content, size and cover on soil erosion dynamics of spoil heaps through multiple rainfall events respectively. This study reveals that the effect of rain drop intensity $\left(\right.$ Eta-square $\left.\left(\eta^{2}\right)=0.8154\right)$ under the bare soil condition accounted for $81.5 \%$ variance in the average detachment rate. This is similar to the works of [28] and [29] for study area with similar conditions.

The relationship between the height difference of simulator and the quantity of soil detached is presented in Table 3 for both the treated and bare soil conditions under the same amount of rainfall intensity and duration. Table 4 reveals that there is a significant difference in the degree of soil detachment between bare and treated soil under simulated rainfall; $\mathrm{t}(8)=3.691, \mathrm{p}<0.05$. The table further presents that bare soil on simulated experiment had a mean value of 7.336 which shows a higher tendency of detachment than that of the treated soil which had a mean value of 4.224. This is in accordance with the works of [30] which compared grain size distribution of sediment and original soil under raindrop detachment and raindrop-induced and flow transport mechanism in Iran. The size of effect (Eta-square $\left(\eta^{2}\right)=0.630$ ) of the intensity reveals that the soil types accounted for $63 \%$ variance as regards the detachment rate.

Table 1. Detached soil particles from both bare and treated soil under natural rainfall.

\begin{tabular}{|c|c|c|c|c|c|c|}
\hline $\mathrm{S} / \mathrm{N}$ & $\begin{array}{l}\text { Date of } \\
\text { rainfall } \\
\text { event }\end{array}$ & $\begin{array}{l}\text { Amount } \\
\text { of rainfall } \\
(\mathrm{mm})\end{array}$ & $\begin{array}{c}\text { Average } \\
\text { soil detached } \\
\text { from bare soil } \\
\qquad\left(\mathrm{g} / \mathrm{m}^{2}\right)\end{array}$ & $\begin{array}{l}\text { Average soil } \\
\text { detached from } \\
\text { treated soil } \\
\left(\mathrm{g} / \mathrm{m}^{2}\right)\end{array}$ & $\begin{array}{l}\text { Calculated } \\
\text { rainfall } \\
\text { intensity } \\
(\mathrm{mm} / \mathrm{hr})\end{array}$ & $\begin{array}{c}\text { Rainfall } \\
\text { kinetic } \\
\text { energy } \\
\left(\mathrm{J} / \mathrm{m}^{2} / \mathrm{mm}\right)\end{array}$ \\
\hline 1 & $14 / 05 / 2016$ & 30.00 & 9.98 & 6.90 & 47.36 & 38.48 \\
\hline 2 & $18 / 05 / 2016$ & 13.10 & 10.91 & 8.24 & 46.24 & 26.56 \\
\hline 3 & $22 / 05 / 2016$ & 32.00 & 11.54 & 7.76 & 73.84 & 39.41 \\
\hline 4 & $27 / 05 / 2016$ & 15.70 & 12.71 & 7.86 & 42.82 & 29.16 \\
\hline 5 & $2 / 6 / 2016$ & 19.60 & 13.80 & 8.27 & 58.80 & 32.35 \\
\hline 6 & $3 / 6 / 2016$ & 12.40 & 13.32 & 8.41 & 74.40 & 25.77 \\
\hline 7 & $5 / 11 / 2016$ & 10.20 & 10.33 & 6.83 & 47.07 & 22.96 \\
\hline 8 & $11 / 11 / 2016$ & 62.40 & 12.36 & 7.81 & 70.64 & 49.01 \\
\hline 9 & $15 / 11 / 2016$ & 12.10 & 11.16 & 7.67 & 48.40 & 25.22 \\
\hline \multirow[t]{2}{*}{10} & $18 / 11 / 2016$ & 9.70 & 10.80 & 7.71 & 58.20 & 22.24 \\
\hline & & $\Sigma=217.20$ & $\sum=116.93$ & $\Sigma=77.51$ & & \\
\hline
\end{tabular}


Table 2. T-test of difference in rate of soil detachment between bare and treated soil under natural rainfall.

\begin{tabular}{ccccccccc}
\hline Variable & $\begin{array}{c}\text { Nature } \\
\text { of soil }\end{array}$ & $\mathrm{N}$ & Mean & St. Dv & df & $\mathrm{t}$ & $\mathrm{sig}$ & $\mathrm{p}$ \\
\hline $\begin{array}{c}\text { Average soil } \\
\text { detached }\end{array}$ & Bare & 10 & 11.691 & 1.294 & 18 & 8.917 & 0.00 & $<0.01$ \\
& Treated & 10 & 7.746 & 0.531 & & & \\
\hline
\end{tabular}

Size of effect (Eta-square $\left.\left(\eta^{2}\right)=0.8154\right)$.

Table 3. Summary of detached soil for bare and treated soil under simulated rainfall.

\begin{tabular}{cccccccc}
\hline $\begin{array}{c}\text { Date of } \\
\text { rainfall } \\
\text { event }\end{array}$ & $\begin{array}{c}\text { Amount } \\
\text { of water } \\
\text { used }\left(\mathrm{cm}^{3}\right)\end{array}$ & $\begin{array}{c}\text { Time spent } \\
\text { before } \\
\text { stopage } \\
(\mathrm{Hr})\end{array}$ & $\begin{array}{c}\text { Average } \\
\text { soil detached } \\
\text { from bare soil } \\
\left(\mathrm{g} / \mathrm{m}^{2}\right)\end{array}$ & $\begin{array}{c}\text { Average soil Calculated } \\
\text { detached }\end{array}$ & $\begin{array}{c}\text { Rainfall } \\
\text { rainfall }\left(\mathrm{g} / \mathrm{m}^{2}\right)\end{array}$ & $\begin{array}{c}\text { kinetic } \\
\text { intensity } \\
(\mathrm{mm} / \mathrm{hr})\end{array}$ & $\begin{array}{c}\text { Height } \\
\text { of rainfall } \\
\left(\mathrm{J} / \mathrm{m}^{2} / \mathrm{mm}\right)\end{array}$ \\
\hline $1 / 10 / 2016$ & 200,000 & 0.08 & 5.59 & 3.49 & 62.50 & 35.29 & 1.00 \\
simulator
\end{tabular}

Table 4. T-test of difference in rate of average soil detachment between bare and treated soil under simulated rainfall.

\begin{tabular}{ccccccccc}
\hline Variable & $\begin{array}{c}\text { Simulated nature } \\
\text { of soil }\end{array}$ & $\mathrm{N}$ & Mean & St. Dv & df & t & Sign & p \\
\hline $\begin{array}{c}\text { Average soil } \\
\text { detachment }\end{array}$ & Bare & 5 & 7.336 & 1.75318 & 8 & 3.691 & 0.006 & $<0.05$ \\
& Treated & 5 & 4.224 & 0.69364 & & & & \\
\hline
\end{tabular}

Size of effect (Eta-square $\left.\left(n^{2}\right)=0.63\right)$.

The bar-chat (Figure 4) reveals that there are little differences in the rate of detachment based on nozzle size. However, nozzle size A3 and A4 tend to create high rate of average soil detachment when compare with those of sizes A1 and A2. Nozzles A1, A2, A3 and A4 had diameter sizes of 0.5, 0.59, 0.67, and 0.78 $\mathrm{mm}$ respectively. Figure 5 shows the relationship between the volume of rainfall and its causative effect on both bear and treated (cow dung) soils indicated that $40.55 \%$ of the soil contents were found to be conserved using the cow dungs mixed with bear soil so as to compact the soil. This is similar to the works of [31] that reviewed the biochar properties and eco-friendly applications for climate change mitigation, waste management, and wastewater treatment. The nature and characteristic of sandy soil makes it easy for detachment to occur; the mixture of cow dungs provides more cohesion that helps in sticking the soil particles together. 


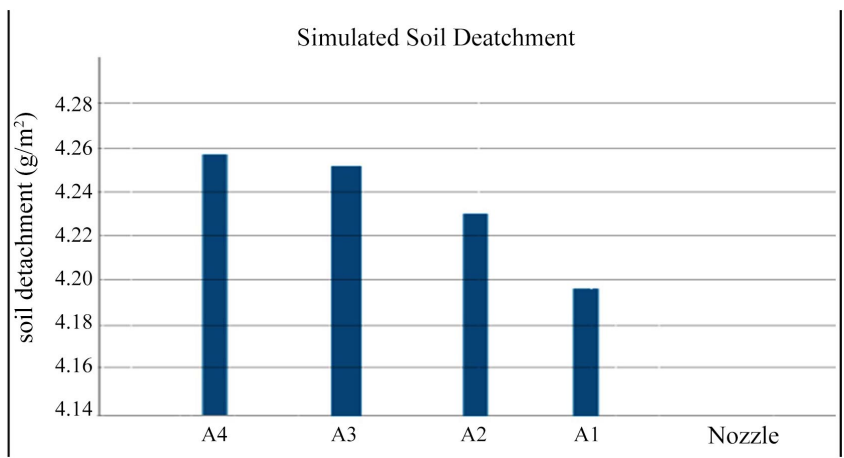

Figure 4. Nozzle size effect on average soil detachment.

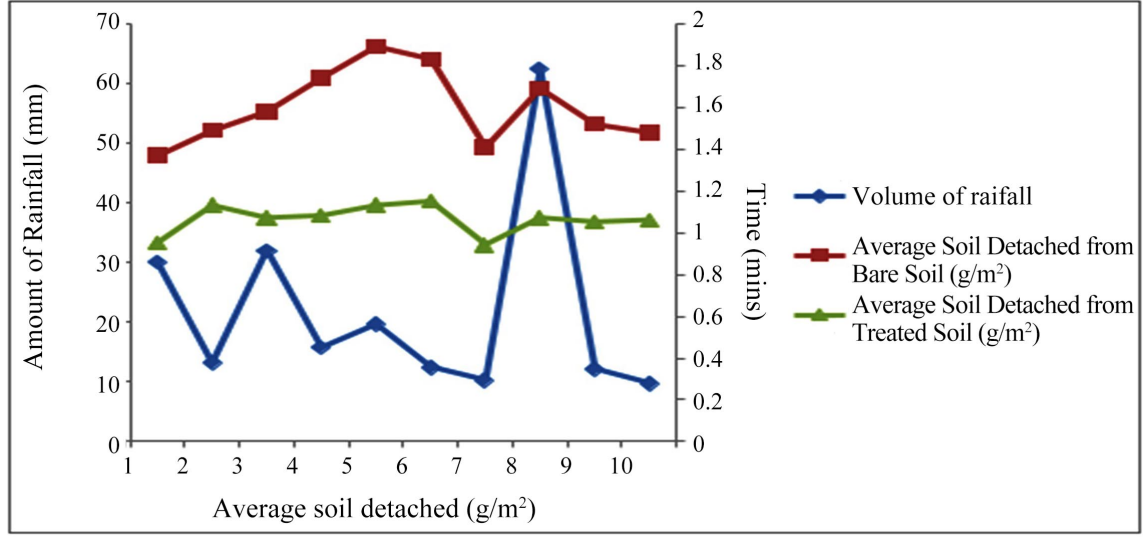

Figure 5. Relationship between volume of rainfall and average soil detached.

The effect of variation in height of the rainfall simulator and the average rate of detachment of treated soils are presented in Figure 6. The chat reveals that the nozzle size and varying height of the rainfall simulator contributed to the average rate of soil detachment. The larger the nozzle size the higher the rate of detachment which is in accordance with the works of [32] and [33]. Figure 7 shows the positive relationship between the heights of simulator and the amount of soil detached. It was observed that the height of rainfall simulator increases the rate at which soil is detached and the rate of soil detachment on the treated soil was relatively small compared to the bear soil. The graph also reveals that the average rate of treated soil detachment is accounted for by the corresponding height of the rainfall simulator. It was observed that the peak of detachment of the soil particles was observed when the rainfall simulator was at a height of 3 meters. This is similar to the findings of [30] and [34]. It was observed that the rate of soil detachment reduced when the height of the rainfall simulator was increased to a height of 3.5 meters.

Detachment occurs based on different factors such as rainfall diameter size, soil type, rainfall intensity and slope of the land. It was observed that the impact of raindrop on the soil created a displacement of soil particle from its initial state, which is in accordance with [35] that rain splash erosion is caused by the kinetic energy of raindrops that strike the soil and throw particles into the air. 


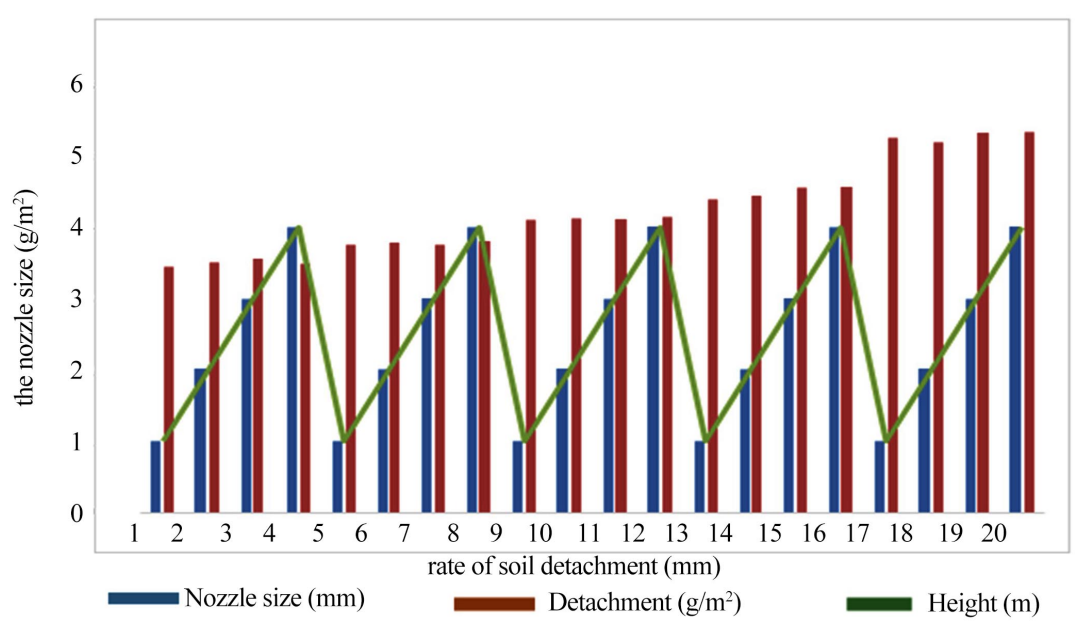

Figure 6. Simulated soil detachment variance.

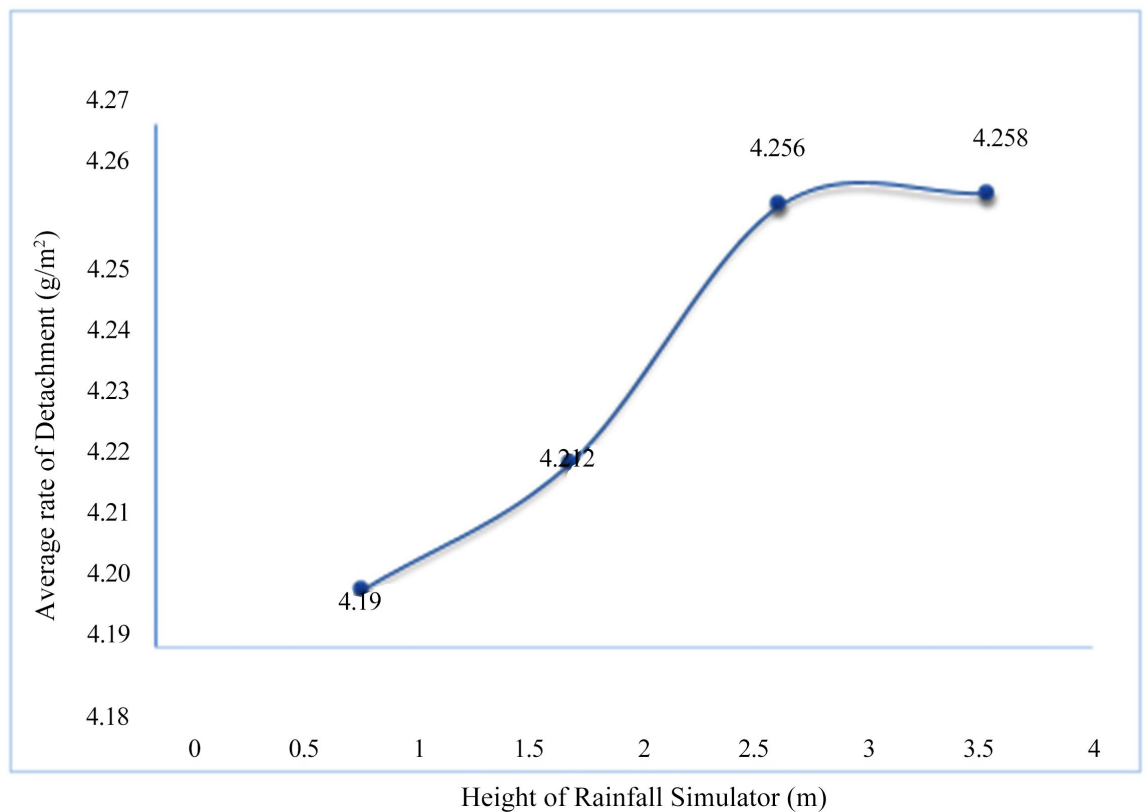

Figure 7. Soil detached $\left(\mathrm{g} / \mathrm{m}^{2}\right)$ against the height of simulator $(\mathrm{m})$ (treated).

Raindrops are major cause of soil splash at the earth surface and make the soil loose susceptible easily to soil erosion, understanding the fact that no rainfall events have the same intensity. It was also reported by [36] that dislodgment of soil is caused by the forces applied on the soil particles by erosive agents, and splash from raindrop impact causes erosion to occur easily. From result obtained, both natural rainfall and the simulator, were observed that the amount of rainfall and its intensity resulted in the amount of soil detached.

The results obtained from the study area indicated that the higher the calculated rainfall intensity and rainfall kinetic energy the greater the bare soil detachment recorded. This is similar to the findings of [37] where they studied the uncertainties in rainfall kinetic energy-intensity relations for soil erosion modelling in four catchment experimental setup areas of NE-Germany. Rainfall energy 
and EI-index were found to be highly correlated with soil detachment as reported by [38] while the lower the amount of rainfall the lesser the bare soil detachment recorded, which shows the significance of those factors.

Similar results were observed from the soils detached from both the natural and the simulator rainfall fields. The rate of detachment of soil particles in the simulated rainfall field was affected by the basic factors such as height of simulator, nozzle sizes, and amount of water released into the pipe for the experiment. The results obtained are similar to the findings of [39] that worked on the contribution of raindrop impact to the change of soil physical properties and water erosion under semi-arid rainfalls while [40] where they carried out a laboratory study on the comparative analysis of splash erosion devices for rainfall simulation experiments and [12] stated that studied the water erosion processes and dynamic changes of sediment size distribution under the combined effects of rainfall and overland flow. This according to [29] that rainfall simulator allows generating rainfall with a known intensity and duration on the plot where experiment is taken place in a controlled manner, making it possible to quantify superficial runoff and soil loss, while at the same time allowing very detailed erosion predictions. It was further observed that the raindrop size from the simulator was the same with two of the natural rainfall events which resulted in the production of the same amount of soil being detached. Different rainfall kinetic energy produced from the natural rainfall generates more detached soil compare to the rainfall simulator.

\section{Conclusion}

Soil loss is generated from the first stage of erosion through raindrop impact on the soil. The soil loss generated by raindrop through simulator and the effect of the conservative measure that was incorporated into the soil were discussed in this thesis. It was therefore concluded that soil detachment, rainfall intensity, and raindrop size data had effect on the quantity of the soil detached from the various land conditions under the natural and simulated rainfall system. The rainfall simulator was found to have been useful to validate results for the natural rainfall event though differences were observed which gave a good correlation between the values of soil lost under the various conditions. The cow dungs were found to be useful in holding the sandy soil particles together thereby reducing the amount of soil detached by $40.33 \%$. Treated soil had significant $(\mathrm{p}<$ $0.01)$ on bare soil under natural rainfall experiment and $(\mathrm{p}<0.05)$ on bare soil under simulator rainfall experiment.

\section{Conflicts of Interest}

The authors declare no conflicts of interest regarding the publication of this paper.

\section{References}

[1] Wenninger, J., Uhlenbrook, S., Lorentz, S. and Leibundgut, C. (2008) Identification 
of Run Off Generation Processes Using Combined Hydrometric, Tracer and Geophysical Methods in a Headwater Catchment in South Africa. Hydrological Sciences Journal, 53, 65-80. https://doi.org/10.1623/hysj.53.1.65

[2] Wang, B., Zhang, G.H., Shi, Y.Y. and Zhang, X.C. (2014) Soil Detachment by Overland Flow under Different Vegetation Restoration Models in the Loess Plateau of China. Catena, 116, 51-59. https://doi.org/10.1016/j.catena.2013.12.010

[3] Shi, Z.H., Fang, N.F., Wu, F.Z., Wang, L., Yue, B.J. and Wu, G.L. (2012) Soil Erosion Processes and Sediment Sorting Associated with Transport Mechanisms on Steep Slopes. Journal of Hydrology, 454, 123-130.

https://doi.org/10.1016/j.jhydrol.2012.06.004

[4] Shi, Z.H., Yue, B.J., Wang, L., Fang, N.F., Wang, D. and Wu, F.Z. (2013) Effects of Mulch Cover Rate on Inter-Rill Erosion Processes and the Size Selectivity of Eroded Sediment on Steep Slopes. Soil Science Society of America Journal, 77, 257-267. https://doi.org/10.2136/sssaj2012.0273

[5] Liu, F., Zhang, G.H., Sun, L. and Wang, H. (2016) Effects of Biological Soil Crusts on Soil Detachment Process by Overland Flow in the Loess Plateau of China. Earth Surface Processes and Landforms, 41, 875-883. https://doi.org/10.1002/esp.3870

[6] Bullard, J.E., Ockelford, A., Strong, C.L. and Aubault, H. (2018) Impact of Multi-Day Rainfall Events on Surface Roughness and Physical Crusting of Very Fine Soils. Geoderma, 313, 181-192. https://doi.org/10.1016/j.geoderma.2017.10.038

[7] Zheng, S., Lourenço, S.D., Cleall, P.J. and Ng, A.K. (2019) Erodibility of Synthetic Water Repellent Granular Materials: Adapting the Ground to Weather Extremes. Science of the Total Environment, 689, 398-412. https://doi.org/10.1016/j.scitotenv.2019.06.328

[8] Dunkerley, D. (2020) A Review of the Effects of Throughfall and Stemflow on Soil Properties and Soil Erosion. In: Precipitation Partitioning by Vegetation, Springer, Cham, 183-214. https://doi.org/10.1007/978-3-030-29702-2_12

[9] Wilson, G.V., Wells, R., Kuhnle, R., Fox, G. and Nieber, J. (2018) Sediment Detachment and Transport Processes Associated with Internal Erosion of Soil Pipes. Earth Surface Processes and Landforms, 43, 45-63. https://doi.org/10.1002/esp.4147

[10] Wu, B., Wang, Z., Zhang, Q. and Shen, N. (2018) Distinguishing Transport-Limited and Detachment-Limited Processes of Interrill Erosion on Steep Slopes in the Chinese Loessial Region. Soil and Tillage Research, 177, 88-96.

https://doi.org/10.1016/j.still.2017.12.005

[11] Santos, J.C.N.D., Andrade, E.M.D., Medeiros, P.H.A., Guerreiro, M.J.S. and Palácio, H.A.D.Q. (2017) Land Use Impact on Soil Erosion at Different Scales in the Brazilian Semi-Arid. Revista Ciência Agronômica, 48, 251-260.

https://doi.org/10.5935/1806-6690.20170029

[12] Hao, H.X., Wang, J.G., Guo, Z.L. and Hua, L. (2019) Water Erosion Processes and Dynamic Changes of Sediment Size Distribution under the Combined Effects of Rainfall and Overland Flow. Catena, 173, 494-504.

https://doi.org/10.1016/j.catena.2018.10.029

[13] Masumian, A., Naghdi, R., Zenner, E.K., Nikooy, M. and Lotfalian, M. (2017) Comparison of Different Erosion Control Techniques in the Hyrcanian Forest in Northern Iran. Journal of Forest Science, 63, 549-554. https://doi.org/10.17221/121/2017-JFS

[14] Solgi, A., Naghdi, R., Labelle, E.R., Behjou, F.K. and Hemmati, V. (2019) Evaluation of Different Best Management Practices for Erosion Control on Machine Operating Trails. Croatian Journal of Forest Engineering. Journal for Theory and Application 
of Forestry Engineering, 40, 319-325. https://doi.org/10.5552/crojfe.2019.532

[15] Cerdà, A., Keesstra, S.D., Rodrigo-Comino, J., Novara, A., Pereira, P., Brevik, E., Giménez-Morera, A., Fernández-Raga, M., Pulido, M., Di Prima, S. and Jordán, A. (2017) Runoff Initiation, Soil Detachment and Connectivity Are Enhanced as a Consequence of Vineyards Plantations. Journal of Environmental Management, 202, 268-275. https://doi.org/10.1016/j.jenvman.2017.07.036

[16] Meyer, L.D. (2017) Rainfall Simulators for Soil Erosion Research. In: Soil Erosion Research Methods, Routledge, Abingdon-on-Thames\$, 83-104. https://doi.org/10.1201/9780203739358-4

[17] Abrantes, J.R., Prats, S.A., Keizer, J.J. and de Lima, J.L. (2018) Effectiveness of the Application of Rice Straw Mulching Strips in Reducing Runoff and Soil Loss: Laboratory Soil Flume Experiments under Simulated Rainfall. Soil and Tillage Research, 180, 238-249. https://doi.org/10.1016/j.still.2018.03.015

[18] Patin, J., Mouche, E., Ribolzi, O., Sengtahevanghoung, O., Latsachak, K.O., Soulileuth, B., Chaplot, V. and Valentin, C. (2018) Effect of Land Use on Interrill Erosion in a Montane Catchment of Northern Laos: An Analysis Based on a Pluri-Annual Runoff and Soil Loss Database. Journal of Hydrology, 563, 480-494.

https://doi.org/10.1016/j.jhydrol.2018.05.044

[19] Wang, L., Fang, N.F., Yue, Z.J., Shi, Z.H. and Hua, L. (2018) Raindrop Size and Flow Depth Control Sediment Sorting in Shallow Flows on Steep Slopes. Water Resources Research, 54, 9978-9995. https://doi.org/10.1029/2018WR022786

[20] Guo, Y. and Yu, X. (2019) Analysis of Surface Erosion of Cohesionless Soils Using a Three-Dimensional Coupled Computational Fluid Dynamics-Discrete Element Method (CFD-DEM) Model. Canadian Geotechnical Journal, 56, 687-698. https://doi.org/10.1139/cgj-2016-0421

[21] Persichillo, M.G., Meisina, C., Cavalli, M., Crema, S. and Bordoni, M. (2016) Understanding the Relationship between Sediment Connectivity and Spatio-Temporal Landscape Changes in Two Small Catchments. Geophysical Research Abstracts. The EGU General Assembly, 3070.

[22] Zhou, Z. and Zhang, X.J. (2019) Impacts of Sediment Load and Size on Rill Detachment under Low Flow Discharges. Journal of Hydrology, 570, 719-725. https://doi.org/10.1016/j.jhydrol.2019.01.033

[23] Dada, P.O.O., Adeyanju, O.R., Adeosun, O.J. and Adewumi, J.K. (2016) Effects of Soil Physical Properties on Soil Loss Due to Manual Yam Harvesting under a Sandy Loam Environment. International Soil and Water Conservation Research, 4, 121-125. https://doi.org/10.1016/j.iswcr.2016.02.007

[24] Barai, V.N., Satpute, G.U. and Atre, A.A. (2018) Effect of Rainfall Intensity on Directional Splash Erosion in Clay Loam Soil under Simulated Condition. International Journal of Bio-Resource and Stress Management, 9, 13-16. https://doi.org/10.23910/IJBSM/2018.9.1.3C0115

[25] Fu, B., Merritt, W.S., Croke, B.F., Weber, T.R. and Jakeman, A.J. (2019) A Review of Catchment-Scale Water Quality and Erosion Models and a Synthesis of Future Prospects. Environmental Modelling \& Software, 114, 75-97.

https://doi.org/10.1016/j.envsoft.2018.12.008

[26] Sandercock, P., Hooke, J., De Baets, S., Poesen, J., Meerkerk, A., van Wesemael, B. and Cammeraat, L.H. (2017) Effectiveness of Plants and Vegetation in Erosion Control and Restoration. In: Combating Desertification and Land Degradation, Springer, Cham, 79-104. https://doi.org/10.1007/978-3-319-44451-2_4

[27] Lv, J., Luo, H. and Xie, Y. (2019) Effects of Rock Fragment Content, Size and Cover 
on Soil Erosion Dynamics of Spoil Heaps through Multiple Rainfall Events. Catena, 172, 179-189. https://doi.org/10.1016/j.catena.2018.08.024

[28] Cheng, Y., Li, P., Xu, G., Li, Z., Wang, T., Cheng, S., Zhang, H. and Ma, T. (2018) The Effect of Soil Water Content and Erodibility on Losses of Available Nitrogen and Phosphorus in Simulated Freeze-Thaw Conditions. Catena, 166, 21-33. https://doi.org/10.1016/j.catena.2018.03.015

[29] Martínez-Mena, M., Carrillo-López, E., Boix-Fayos, C., Almagro, M., Franco, N.G., Díaz-Pereira, E., Montoya, I. and de Vente, J. (2020) Long-Term Effectiveness of Sustainable Land Management Practices to Control Runoff, Soil Erosion, and Nutrient Loss and the Role of Rainfall Intensity in Mediterranean Rainfed Agroecosystems. Catena, 187, Article ID: 104352. https://doi.org/10.1016/j.catena.2019.104352

[30] Kiani-Harchegani, M., Sadeghi, S.H. and Asadi, H. (2018) Comparing Grain Size Distribution of Sediment and Original Soil under Raindrop Detachment and Raindrop-Induced and Flow Transport Mechanism. Hydrological Sciences Journal, 63, 312-323. https://doi.org/10.1080/02626667.2017.1414218

[31] Qambrani, N.A., Rahman, M.M., Won, S., Shim, S. and Ra, C. (2017) Biochar Properties and Eco-Friendly Applications for Climate Change Mitigation, Waste Management, and Wastewater Treatment: A Review. Renewable and Sustainable Energy Reviews, 79, 255-273. https://doi.org/10.1016/j.rser.2017.05.057

[32] Lu, J., Zheng, F., Li, G., Bian, F. and An, J. (2016) The Effects of Raindrop Impact and Runoff Detachment on Hillslope Soil Erosion and Soil Aggregate Loss in the Mollisol Region of Northeast China. Soil and Tillage Research, 161, 79-85. https://doi.org/10.1016/j.still.2016.04.002

[33] Kavian, A., Mohammadi, M., Cerda, A., Fallah, M. and Abdollahi, Z. (2018) Simulated Raindrop's Characteristic Measurements. A New Approach of Image Processing Tested under Laboratory Rainfall Simulation. Catena, 167, 190-197. https://doi.org/10.1016/j.catena.2018.04.034

[34] Naves, J., Anta, J., Suárez, J. and Puertas, J. (2020) Development and Calibration of a New Dripper-Based Rainfall Simulator for Large-Scale Sediment Wash-Off Studies. Water, 12, 152. https://doi.org/10.3390/w12010152

[35] Wischmeier, W.H. and Smith, D.D. (1978) Predicting Rainfall Erosion Losses. Handbook No. 537, USDA, Washington DC.

[36] Geng, R., Zhang, G.H., Ma, Q.H. and Wang, H. (2017) Effects of Landscape Positions on Soil Resistance to Rill Erosion in a Small Catchment on the Loess Plateau. Biosystems Engineering, 160, 95-108. https://doi.org/10.1016/j.biosystemseng.2017.06.001

[37] Wilken, F., Baur, M., Sommer, M., Deumlich, D., Bens, O. and Fiener, P. (2018) Uncertainties in Rainfall Kinetic Energy-Intensity Relations for Soil Erosion Modelling. Catena, 171, 234-244. https://doi.org/10.1016/j.catena.2018.07.002

[38] Singh, M. and Hartsch, K. (2019) Basics of Soil Erosion. In: Watershed Hydrology, Management and Modeling, CRC Press, Boca Raton, 1-61. https://doi.org/10.1201/9780429430633-3

[39] Vaezi, A.R., Ahmadi, M. and Cerdà, A. (2017) Contribution of Raindrop Impact to the Change of Soil Physical Properties and Water Erosion under Semi-Arid Rainfalls. Science of the Total Environment, 583, 382-392. https://doi.org/10.1016/j.scitotenv.2017.01.078

[40] Fernández-Raga, M., Campo, J., Rodrigo-Comino, J. and Keesstra, S.D. (2019) Comparative Analysis of Splash Erosion Devices for Rainfall Simulation Experiments: A Laboratory Study. Water, 11, 1228. https://doi.org/10.3390/w11061228 